\section{Ankylosing Spondylitis Refractory to Tumor Necrosis Factor Blockade Responds to Tocilizumab}

\section{To the Editor:}

Tumor necrosis factor- $\alpha$ (TNF- $\alpha$ ) antagonists are highly effective in treatment of ankylosing spondylitis (AS). However, some patients have an inadequate response and switching the anti-TNF- $\alpha$ inhibitors may be effective after an initial failure ${ }^{1}$. No other biologicals are approved for patients failing anti-TNF therapy. We describe a case of severe AS that was successfully treated with tocilizumab, the interleukin 6 (IL-6) receptor antagonist, after failing all 3 available anti-TNF- $\alpha$ inhibitors.

A 45-year-old man had had B27-positive AS without peripheral arthritis since 1996. After insufficient responses to nonsteroidal antiinflammatory drugs, he responded to infliximab $(5 \mathrm{mg} / \mathrm{kg})$ for 4.5 years. Because of secondary inefficacy, he was switched to etanercept, without effect, and then adalimumab. After 1 year, he experienced flare; tocilizumab $8 \mathrm{mg} / \mathrm{kg}$ intravenously was started. After the first infusion he reported a rapid decrease of pain and morning stiffness. At 4 weeks, the Bath Ankylosing Spondylitis Disease Activity Index (BASDAI) improved from 3 to 0.9 , the Bath Ankylosing Spondylitis Functional Index decreased from 6 to 1.5, and the Ankylosing Spondylitis Disease Activity Score (ASDAS) ${ }^{2}$ decreased from 2.2 to 1.3. The laboratory measures of inflammation had always been normal. Because of the recurrence of symptoms after 3 weeks, we increased the infusion frequency to every 3 weeks. After 6 infusions, we changed back to the original 4-week frequency. After 12 months of therapy, the patient could be considered in remission, with ASDAS at 0.9 .

High levels of IL- 6 have been observed in the serum ${ }^{3}$ and sacroiliac biopsy samples ${ }^{4}$ of patients with AS, suggesting a role for IL-6 in AS. The effect of IL-6 blockade in spondyloarthritis was first reported in a patient with reactive arthritis receiving a murine anti-IL-6 antibody ${ }^{5}$. Few cases with use of tocilizumab have been published: in $\mathrm{AS}^{6,7}$, AS with Crohn's disease $^{8}$, and in reactive arthritis ${ }^{9}$. In some cases, improvement of the laboratory markers for inflammation probably explains the greater ${ }^{7}$ or exclusive $^{6}$ effects on ASDAS compared to BASDAI scores. In this respect, it should be noted that in our patient the efficacy of tocilizumab measured as improvement of ASDAS was independent of measures of C-reactive protein (CRP). Moreover, in contrast to clinical improvement, spinal inflammation assessed by magnetic resonance imaging can persist ${ }^{7}$ in spite of a correlation with levels of IL- $6^{10}$. The frequency of tocilizumab infusions could be different for AS than for rheumatoid arthritis. Thus, as in another case $^{8}$, we successfully increased the frequency of perfusions.

Our case experience suggests that tocilizumab could be used in patients with AS refractory to anti-TNF- $\alpha$ inhibitors, and may be clinically relevant and not artificially related to a decrease of CRP. However, controlled studies to confirm these hypotheses are warranted.
JEAN-DAVID COHEN, MD; ROSANNA FERREIRA, MD; CHRISTIAN JORGENSEN, MD, Hopital Lapeyronie, Unité d'Immuno-Rhumatologie, 191 avenue du doyen Gaston Giraud, Montpellier 34295, France. Address correspondence to Dr. Cohen;

E-mail: jd-cohen@chu-montpellier.fr

\section{REFERENCES}

1. Lie E, van der Heijde D, Uhlig T, Mikkelsen K, Rødevand E, Koldingsnes W, et al. Effectiveness of switching between TNF inhibitors in ankylosing spondylitis: data from the NOR-DMARD register. Ann Rheum Dis 2011;70:157-63.

2. Machado P, Landewé R, Lie E, Kvien TK, Braun J, Baker D, et al Ankylosing Spondylitis Disease Activity Score (ASDAS): defining cut-off values for disease activity states and improvement scores. Ann Rheum Dis 2011;70:47-53.

3. Bal A, Unlu E, Bahar G, Aydog E, Eksioglu E, Yorgancioglu R. Comparison of serum IL-1 beta, sIl-2R, IL-6, and TNF- $\alpha$ levels with disease activity parameters in ankylosing spondylitis. Clin Rheumatol 2007;26:211-5.

4. Francois RJ, Neure L, Sieper J, Braun J. Immunological examination of open sacroiliac biopsies of patients with ankylosing spondylitis: detection of tumour necrosis factor alpha in two patients with early disease and transforming growth factor beta in three more advanced cases. Ann Rheum Dis 2006;65:713-20.

5. Wendling D, Racadot E, Toussirot E, Wijdenes J. Combination therapy of anti-CD4 and anti-IL-6 monoclonal antibodies in a case of severe spondylarthropathy. Br J Rheumatol 1996;35:1330.

6. Wendling D, Bossert M, Prati C. Short-term effect of IL-6 inhibition in spondylarthritis. Joint Bone Spine 2010;77:624-5.

7. Henes JC, Horger M, Guenaydin I, Kanz L, Koetter I. Mixed response to tocilizumab for ankylosing spondylitis. Ann Rheum Dis 2010;69:2217-8.

8. Brulhart L, Nissen MJ, Chevallier P, Gabay C. Tocilizumab in a patient with ankylosing spondylitis and Crohn's disease refractory to TNF antagonists. Joint Bone Spine 2010;77:625-6.

9. Tanaka T, Kuwahara Y, Shima Y, Hirano T, Kawai M, Ogawa M, et al. Successful treatment of reactive arthritis with a humanized anti-interleukin-6 receptor antibody, tocilizumab. Arthritis Rheum 2009;61:1762-4.

10. Visvanathan V, Wagner C, Marini JC, Baker D, Gathany T, Han $\mathrm{J}$, et al. Inflammatory biomarkers, disease activity and spinal disease measures in patients with ankylosing spondylitis after treatment with infliximab. Ann Rheum Dis 2008;67:511-7.

J Rheumatol 2011;38:7; doi:10.3899/jrheum.110265 